research and development. In doing so, he or she will find it necessary to ask whether the condition of the French university system is entirely suited to present needs. In the past seven years of the presidency now ending, much has been done pragmatically to improve the lot of the universities, but very little is written down on paper. The new president seems to have been offering the nearest that France would accept to an American way of administering science. The question still to be answered is whether he will discover, in this connection too, that tradition goes deeper than voting behaviour.

\section{Calculating flop}

The British government, always ready to seek to demonstrate that water can be made to run uphill by a sufficient display of determination, has been in trouble for several weeks because it insists on willing that Britain, like the United States, should enjoy the benefits of an indigenous, productive, competitive and profitable mainframe computer manufacturer. The trouble came to a head on Monday, when the chairman and managing director of the company called International Computers Limited (ICL for short) resigned, after the Department of Industry had put a pistol to their heads and asked that they should accept a new way of working. Mr Phillip Chappell, the part-time chairman for just over a year, will go back to being a full-time merchant banker. His managing director, Dr Christopher Wilson, will remain a director of ICL (and will be paid an executive director's salary). $\mathrm{Mr}$ Chappell and Dr Wilson are replaced by two outsiders - Mr C. C. F. Laidlaw, vice-chairman of British Petroleum Ltd, as chairman and Mr Robert Wilmot (now managing director of the British end of Texas Instruments) as the new managing director. The government's headhunters have done well; the new management has at least as good a chance of succeeding as the old. But the chances are not high, and it is in the (British) public interest that everybody concerned should acknowledge that to be the case.

ICL has a long distinguished history, going back to the end of the Second World War. That was when people straight out of the design of radar systems settled down to making electronic versions of the old electromechanical calculating "engines"'. For a time, at least in Britain, it seemed that success exceeded all reasonable expectations. A private company called Ferranti was closely involved with the development of a computing system at the University of Manchester, linked with the names of people such as Thuring and F. C. Williams. The first prototype of this computer was frequently inspected by admiring visitors from other computer companies, many of them from overseas. In due course, when it seemed likely that an electronic computing machine of some kind might sell and make money, the then British government negotiated with Ferranti an arrangement under which there would be a public subsidy to help put this new machine on the market. The amount concerned, just over $£ 1$ million, was tiny in comparison with the task. But Ferranti chose to spend this pittance not on the development of a commercial market but on the development of a more advanced and less successful machine.

With the passage of the decades (almost exactly two of them), it became plain that the promise of the immediate post-war period had not been fulfilled. By 1968, the turnover of IBM World Trade (the overseas arm of IBM Inc.) probably exceeded the annual exports of the United Kingdom. Enthused by a vision of a brave new technical world, however, $\mathrm{Mr}$ (now Sir) Harold Wilson, then the British Prime Minister, set up an organization called the Industrial Reorganisation Corporation to effect the merger of companies judged too small to compete on their own with the giants overseas. In 1968, Ferranti's computer interests, together with those of the other British manufacturers eager to build mainframe computers, were welded together with the help of public money. The stage was set for the emergence of a giant to complete with IBM et al. The snag was that nobody thought, knew or seemed to care what kind of company ICL should be so long as it was big.
This week's announcement that the management must be changed yet again is therefore a sign that water is still steadfastly refusing to flow uphill. The attempts by successive British governments to give ICL an inside track in the supply of computers for the public sector has most often been defeated by the preference of the intended customers for somebody else's machines. ICL shares with the most successful of its overseas competitors, even IBM, the fault of not having judged just when small computers would come into their own. Unlike some of them, it has been too insecure to ride this tide. Now, it seems, ICL is hoping to make up with its flair for distributed computer networks for its failure to make much money on the huge machines that are its pride and joy. British taxpayers in particular will wish it luck. In the next two years, the company will survive with the help of a loan of $£ 270$ million from the commercial banks, $£ 200$ million of which is underwritten by the government on behalf of the taxpayers.

In retrospect, what went wrong at ICL was not the decision (in 1968 ) that there should be a unified computer company, nor the British government's repeated reappointment of new managers, but the failure to acknowledge at the outset that in a novel field of technology, it is impossible to design by means of a committee the commercial enterprise that is certain to carry off the prize. The best that can be hoped for is to send several arrows at the target.

The irony in all this is that British government's stake in ICL is now much less than it used to be a year ago. Technically, the company is much more directly under the control of its private shareholders than of the Department of Industry since the government and some other big shareholders sold out to the general public at the top of the market. But ICL will remain in hock to the department so long as the $£ 40$ million public loan arranged some years ago remains unpaid. For the whole of that time, British governments will find it necessary to worry about the strategic value of companies such as ICL. Some of them may be able to stomach pulling out of old industries such as shipbuilding, but pulling out of computer manufacturing may seem like turning the back on the future. In ICL's present crisis, all kinds of interests are seeking to persuade the British government of that truth. But it is not a truth at all, of course. Consistently unprofitable companies serve no purpose and should be put to sleep, whatever they happen to be making.

\section{Tokenism again}

Public officials, who necessarily spend their waking hours in committee meetings, naturally believe that appearance is reality. For the past several years, but especially since the appearance of the Finniston Report on engineering education eighteen months ago, the British government and the whole company of its officials have been dedicated to the belief that the status of engineering as a profession and of engineers as people must somehow be enhanced. Otherwise, the argument goes, British manufacturing industry will continue to be uncompetitive and will go out of business.

Dr Duncan Davies, until last month Chief Scientist and Engineer at the Department of Industry, and Sir Geoffrey Allen, the chairman of what used to be the Science Research Council, have shown what can be done. Dr Davies has rechristened himself "Chief Engineer and Scientist". Allen's research council, with the help of Queen Elizabeth II, has been renamed the Science and Engineering Research Council. Everybody concerned proclaims that the change of name does not mean a change of function. But engineers (as distinct from scientists) will walk a little taller. And the only cost will be that charged by the suppliers of printed stationery to public agencies and corporations. Nobody seems alarmed that the chief recommendation of the Finniston Report - that there should be an Engineering Council to regulate the profession of engineer - has still not been set up.

At a meeting on Thursday this week, the unions claiming to represent professional engineers will be throwing yet more sand in the works. Tokenism, not the best policy, may be the only one. 